\title{
Performance Evaluation of Hot Mixture Asphalt Using Concentrated Rubber Latex, Rubber Compound and Synthetic Polymer as Modifier
}

\author{
Suaryana, N..$^{*}$ and Sofyan, T.S. ${ }^{2}$
}

\begin{abstract}
Research on the utilization of natural rubber for Hot Mixture Asphalt (HMA) as modifier has been widely carried out, and more intensively since 2016 due to the declining global natural rubber price. Further research conducted is the utilization of pre-vulcanized concentrated rubber latex and rubber compound added with antioxidants and treated through vulcanization process. This study experimentally evaluates the performance of Asphalt Concrete Wearing Course (ACWC) using natural rubber and synthetic polymer as modifier, compared to ACWC without modifier (only petroleum asphalt). The results show that the rubberized asphalt has higher index penetration value as well as higher elasticity compared to petroleum asphalt penetration grade 60, but lower than synthetic polymer modified asphalt. Similarly, the level of performance of rubberized asphalt mixtures, particularly resilient modulus, water resistance, deformation, and fatigue cracking, is between that of petroleum asphalt and synthetic polymer modified asphalt.
\end{abstract}

Keywords: Latex; modifier; polymer; performance; rubber compound.

\section{Introduction}

Latex is a term used to refer to the sap from rubber tree. Natural latex is obtained from Hevea Brasiliensis plant, then processed and traded as industrial material in the form of rubber smoked sheet (RSS), concentrated latex, crumb rubber, and others. Indonesia is the second largest natural rubber producers after Thailand. Indonesia's natural rubber production is currently 3.2 million tons with the plantation area of 3.6 million hectares. The production of natural rubber in Indonesia is dominated by crumb rubber products, around 97\%, 2.5\% rubber sheet, $0.25 \%$ concentrated rubber latex, and others $0.25 \%$ [1]. The use of rubber as an additive material for asphalt as an attempt to improve the asphalt elasticity, resistance to high temperature, and durability, has been known since a long time ago. Natural rubber latex has been scientifically proven can be used as a modifier for asphalt [2]. In addition, it is more efficient in terms of processing costs, usage levels, storage preparation, and stability, compared to the use of natural rubber powder or waste/scrap tires [2]. According to Tuntiworawit et al. [3], once asphalt is mixed with latex at high temperature, the rubber particles will expand and absorb the light oil in asphalt.

1,2 Institute of Road Engineering, Jl A.H Nasution No. 264 Bandung 40294, INDONESIA

*Corresponding author; email: nyomansuaryana@yahoo.com

Note: Discussion is expected before June, $1^{\text {st }} 2019$, and will be published in the "Civil Engineering Dimension", volume 21, number 2, September 2019.

Received 19 February 2019 revised 14 March 2019; accepted 26 March 2019
The addition of latex makes the asphalt become more viscous and elastic. The use of rubberized asphalt as a binder on asphalt mixture will result in thicker bitumen films, thus it will increase the adhesiveness between the aggregates and the asphalt. At low temperature, the asphalt mixture is susceptible to crack due to stress, adding latex as a modifier, therefore will increase elasticity and viscosity which makes it not easily cracked. Whilst at high temperature, latex will perform as membranes that resist asphalting melting and increasing shear strength [4]. Mixing latex with asphalt has a problem of frothing and foaming because latex contains water, due to high temperature of heating during the mixing process with asphalt, Vichitcholchai et al. [5] conducted a study using Rubber Smoked Sheet (RSS) to prevent frothing and foaming. The results obtained showed an increase in physical properties of asphalt such as, low penetration value, high softening point, high penetration index, high torsional recovery, and high toughness, which the most effective proportion of RSS is $6 \%$ of the asphalt mass. Another alternative is using Liquid Natural Rubber (LNR) which results in more homogeneous mixture, makes it easier to blend with asphalt as frothing and foaming problems due to water evaporation that can be distracted by the elimination at fall temperatures [6]. Another form of raw rubber, for instance cup lump rubber, has met requirements to be used as an additive to the conventional road materials. Cup lump is freshly coagulated rubber where the coagulation process takes place in a cup attached in a tree. It is seen as a new alternative for long term solution to increase domestic consumption of natural rubber through its application with asphalt materials [7]. As an attempt to increase domestic natural rubber 
price, Indonesia has been undertaking research and developed on utilizing latex natural rubber that has been through the vulcanization process, as well as utilizing crumb rubber by making compound which is a mixture of crumb rubber with sulfur, antioxidants, and with/without asphalt. There are several advantages of using processed natural rubber, for instance good storage stability, more resistant to heat and oxidation, and easier in the process of mixing with asphalt. This study aims to obtain appropriate technology in the use of natural rubber as asphalt modifier.

\section{Experimental Materials and Methods}

This research uses an experimental method by conducting laboratory test. Four types of asphalt and asphalt modified are used, such as; (i) petroleum asphalt penetration grade of 60 (pen 60), (ii) asphalt pen 60 plus prevulcanized concentrated latex, (iii) asphalt pen 60 plus rubber compound, and (iv) asphalt pen 60 plus synthetic polymers. HMA mixtures of Asphalt Concrete Wearing Course (ACWC) are developed by using the four types of asphalts, and then their performances are compared. The research stages include literature study, material characteristic testing, mixing design (Marshall), ACWCmix performance testing including resilient modulus testing, resistance to flow/deformation testing, and resistance to fatigue crack testing. Design for the asphalt mixture uses the Marshall method refers to AASHTO T 245 [8], and the moisture susceptibility is performed by Indirect Tensile Strength Ratio (ITSR) in accordance to ASSHTO T283-89 [9]. The resilient modulus testing in the laboratory refers to ASTM D7369-11[10]. For laboratory testing for deformation resistance, Wheel Tracking Machine (WTM) is used, and the test method refers to Japan Road Association 1980 [11]. While for the resistance to fatigue crack testing, fatigue testing machine testing namely Beam Fatigue (BFA) is used in accordance to AASHTO T 321-14 [12].

\section{Sample Preparation}

\section{Aggregates and Petroleum Asphalt Penetra- tion Grade 60}

The aggregate used comes from West Java areas, and the petroleum asphalt have penetration grade 60 and produced by PT. Pertamina. The aggregate, aggregate combined gradation, and asphalt used must meet the requirement for Asphalt Concrete Wearing Course (ACWC) according to SNI 8198: 2015 [13].

\section{Rubberized Asphalt with Concentrated Latex}

Natural latex is processed by centrifuging into concentrated latex containing $60 \%$ dry rubber by mass with low ammonia content. The concentrated latex is then vulcanized by adding sulfur through heating process to gain strong and durable rubber. Antioxidant is also added to reduce the effect of oxidation on rubber. Rubberized asphalt is prepared by mixing asphalt pen 60 with pre-vulcanized concentrated latex, its dosage is $7 \%$ of the asphalt mass. This dosage is chosen based on trials at the Institute of Road Engineering in simultaneous research. The mixing process is carried out by stirring slowly for 4 hours at $150{ }^{\circ} \mathrm{C}$, therefore the water content evaporates and develops homogeneous and ready-to-use pre-mixture rubberized asphalt. The pre-mixture asphalt rubber with pre-vulcanized concentrated latex as modifier is called as rubberized asphalt L.

\section{Rubberized Asphalt with Rubber Compound}

Natural latex is processed by agglomerating into solid rubber, refers to quality class of Technical Specified Rubber (TSR) or in Indonesia known as quality class of Standard Indonesian Rubber (SIR). This study uses SIR 20 solid natural rubber. The solid natural rubber is used as the base material of rubber compound, and processed by adding sulfur (vulcanization) as well as activator, accelerator, softener, and antioxidant. The activator and accelerating materials are added to the vulcanization system to accelerate the vulcanization process. The softener is a chemical which added to the raw rubber during the process of preparing the rubber compound, in order to soften the rubber and ease the mixing of rubber chemicals. Antioxidants are added in the making of compounds to protect the rubber before and after the vulcanization from aging or oxidation, heat, sunlight (ozone), and mechanical effects. Natural rubber has natural antioxidant material, however, because of its low content it is unable to protect the rubber through the oxidation process. If the antioxidant material is not added on the rubber, the rubber will easily be sticky and soft then become hard and cracked or fragile. The next step is mixing rubber compound with petroleum asphalt pen 60 , its dosage is $7 \%$ of the asphalt mass. The mixing process uses a colloid mill to get homogeneous and ready-to-use pre-mixture rubberized asphalt. This pre-mixture rubberized asphalt with rubber compound as modifier is called as rubberized asphalt $\mathrm{C}$.

\section{Modified Asphalt with Synthetics Polymer}

Asphalt pen 60 is mixed with synthetic polymers namely Styrene Butadiene Styrene (SBS) in bitumen plant using a colloid mill mixer. SBS content in Polymer Modified Bitumen (PMB) asphalt is about $4.5 \%$ by mass (the dosage is chosen to reach a minimum softening point of $54{ }^{\circ} \mathrm{C}$ ). The pre-mixture synthetic polymers modified asphalt is called as PMB. 


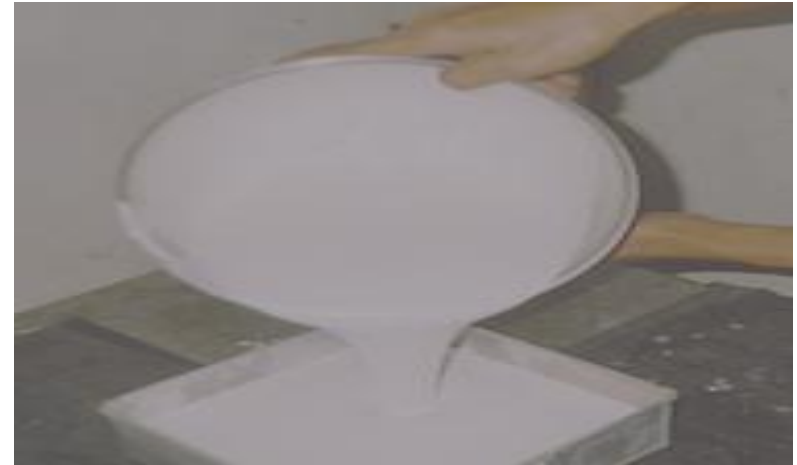

(a)



(b)

Figure 1. (a) Latex and (b) Rubber Compound

\section{Analysis and Discussion of Results}

\section{Asphalt Characteristics}

Characteristics of four kinds of bitumen, i.e. petroleum asphalt pen 60, petroleum asphalt modified by $7 \%$ by mass of pre-vulcanized latex (rubberized asphalt L), petroleum asphalt modified by $7 \%$ by weight of natural rubber compound (rubberized asphalt (C), and petroleum asphalt modified by $4.5 \%$ styrene butadiene styrene (referred to as PMB), as listed in Table 1.

The temperature susceptibility is described as the change of primary or routine rheological properties of asphalt with temperature. Pleiffer and Van Dormaal [14] defined the temperature susceptibility of asphalt as the Penetration Index (PI), the value of PI ranges from -3 for highly temperature susceptible asphalt to about +7 for highly blown low temperature susceptible asphalt. The equation is:

$$
P I=\frac{1952-500 \log P e n-20(S P)}{50 \log P e n-(S P)-120}
$$

where:

Pen $=$ Penetration $(\mathrm{dmm})$

$\mathrm{SP}=$ Softening Point $\left({ }^{\circ} \mathrm{C}\right)$

Based on the data in Table 1 and the implementation of the Equation (1), the results show that the Penetration Index (PI) of Pen 60 is -0.99 , rubberized asphalt $\mathrm{L}$ is -0.16 , rubberized asphalt $\mathrm{C}$ is -0.05 and $\mathrm{PMB}$ is +0.41 . The results show that the rubberized asphalt has less sensitivity to temperature than the petroleum asphalt pen 60 but still under PMB. Rubberized asphalt uses rubber compound is slightly better than pre-vulcanized concentrated latex, it is because the process of making the rubberized asphalt rubber compound needs more repetitive heating than rubberized asphalt concentrated latex. The heating process applied in each step results in light oil (maltene) evaporation therefore rubberized asphalt becomes tougher (low penetration). Rubberized asphalt increases the elasticity of the asphalt as shown in the elastic recovery value that becomes greater. The elasticity of rubberized asphalt with pre-vulcanized latex is better than the rubberized asphalt compound. It is caused by the different process of production, where pre-vulcanized latex is heated only at the time of vulcanization process, while the rubberized asphalt compound is heated again during the early mixing with asphalt.

\section{Aggregates Characteristics}

Several tests have been conducted to determine the aggregate characteristics used, the results are shown in Table 2. The combination aggregates gradation follows the middle value of the gradation envelope for asphalt concrete wearing course (ACWC) according to the requirements listed in SNI 8198:2015 [13]

\section{Mixture Characteristics}

Marshall testing is conducted for Asphalt Concrete Wearing Course (ACWC) mixture. In the process of making a mix design, the Marshall Test sample is made in 5 variations in asphalt content, namely $5.0 \%, 5.5 \%, 6.0 \%, 6.5 \%$, and $7.0 \%$. Then the optimum asphalt content was chosen which fulfilled all the Marshall criteria according to SNI 8198:2015 [13]. The comparison of the results of Marshall Test on optimum asphalt content is shown in Table 3.

The optimum asphalt content and volumetric characteristics of ACWC asphalt mixture obtained from the design are relatively similar. However, the result of stability test of mixture using rubberized asphalt tends to be higher than that of hot mix asphalt with asphalt pen 60. The asphalt mixture with PMB asphalt has the highest value of stability.

The sensitivity of asphalt mixture to the effect of moisture can be seen from the value of Indirect Tensile Strength Ratio (ITSR) or from Marshall Retained Stability. According to the data listed in Table 3, the rubberized asphalt can increase the resistance to moisture effect compared to conventional asphalt mixture with petroleum asphalt pen 60. The increasing resistance to water proves that natural rubber can improve the adhesiveness of asphalt and aggregate. 
Table 1. Asphalt and Asphalt Modified Characteristics

\begin{tabular}{clccccc}
\hline No & \multicolumn{1}{c}{ Characteristics } & Pen 60 & $\begin{array}{c}\text { Spesification } \\
\text { SNI 8198:2015 }\end{array}$ & $\begin{array}{c}\text { Rubberized } \\
\text { Asphalt L }\end{array}$ & $\begin{array}{c}\text { Rubberized } \\
\text { Asphalt C }\end{array}$ & PMB \\
\hline 1 & Penetration, dmm & 63 & $60-70$ & 53 & 51 & 57 \\
2 & Softening point, ${ }^{\circ} \mathrm{C}$ & 48.7 & $>48$ & 53.8 & 54.7 & 55.5 \\
3 & Ductility at $25^{\circ} \mathrm{C}, \mathrm{cm}$ & $>140$ & $>100$ & $>140$ & $>140$ & $>140$ \\
4 & Flash point, ${ }^{\circ} \mathrm{C}$ & 328 & $>280$ & 320 & 314 & 310 \\
5 & Specific gravity & 1.035 & $>1.0$ & 1.023 & 1.038 & 1.035 \\
4 & Solubility & 99.8 & $>99$ & 99.2 & 99.7 & 99.9 \\
6 & Storage stability & - & & 0.95 & 0.85 & 1.2 \\
& Residue results of Thin Film Oven Test (TFOT) & & & & \\
7 & Loss of Heating (LoH), $\%$ & 0.019 & $>0.8$ & 9.015 & 0.017 & 0.013 \\
8 & Penetration after LoH, $\%$ & 82.1 & $>54$ & $>140$ & 79.5 & 82.5 \\
9 & Ductility at $25^{\circ} \mathrm{C}$ after LoH, cm & $>140$ & $>100$ & 53.7 & 32.5 & $>140$ \\
10 & Elastic recovery after LoH, \% & 10.8 & - & & & 63.8 \\
\hline
\end{tabular}

Table 2. Aggregates Characteristics

\begin{tabular}{|c|c|c|c|c|c|c|}
\hline \multirow[b]{2}{*}{ No } & \multirow[b]{2}{*}{ Characteristics } & \multirow[b]{2}{*}{ Method of Testing } & \multicolumn{3}{|c|}{ Testing Results } & \multirow[b]{2}{*}{$\begin{array}{c}\text { Spesification } \\
\text { SNI 8198:2015 }\end{array}$} \\
\hline & & & $\begin{array}{c}\text { Coarse } \\
\text { Aggregate } \\
(10-20)\end{array}$ & $\begin{array}{l}\text { Medium } \\
\text { Aggregate } \\
(5-10)\end{array}$ & $\begin{array}{c}\text { Fine } \\
\text { Aggregate } \\
(0-5)\end{array}$ & \\
\hline 1. & L.A Abrasion loss, (\%) & SNI 03-2417-2008 & 20 & - & - & Maks. 30 \\
\hline 2. & Sand Equivalent, (\%) & SNI 03-4428-1997 & - & - & 61 & Min. 60 \\
\hline \multirow[t]{4}{*}{3.} & Spesific Gravity & & & & & \\
\hline & Bulk & SNI 03-1969-2008 & 2.63 & 2.66 & 2.63 & - \\
\hline & $S S D$ & $\&$ & 2.66 & 2.68 & 2.68 & - \\
\hline & Apparent & SNI 03-1970-2008 & 2.76 & 2.77 & 2.77 & - \\
\hline 4. & Absorbtion, (\%) & SNI 031969 -2008 & 1.7 & 1.5 & 1.9 & Maks. 3.0 \\
\hline 5. & Angularity of fine aggregate, (\%) & SNI 03-6877-2002 & - & - & 46 & Min. 45 \\
\hline 6. & Angularity of coarse aggregate, (\%) & ASTM D 58212001 & 99.3/99.2 & - & - & $95 / 90$ \\
\hline 7. & $\begin{array}{l}\text { Coating and Stripping of bitumen- } \\
\text { aggregate,(\%) }\end{array}$ & SNI 03-2439-2011 & - & $95+$ & - & Min. 95 \\
\hline 8. & Flat and Elongated Particles, (\%) & ASTM D 47912005 & 2.4 & - & - & Maks. 10 \\
\hline 9. & Weathering, $(\%)$ & SNI 03-3407-1994 & 1.5 & 2.1 & 2.8 & Maks. 12 \\
\hline
\end{tabular}

Table 3. Mixture Characteristics

\begin{tabular}{clcccc}
\hline \multirow{2}{*}{ No. } & \multicolumn{1}{c}{ Marshall Criteria } & \multicolumn{4}{c}{ ACWC Mixture } \\
\cline { 3 - 6 } & & Pen 60 & Rubberized Asphalt L & Rubberized Asphalt C & PMB \\
\hline 1 & Optimum Asphalt Content, (\%) & 6.03 & 6.08 & 6.13 & 6.05 \\
2 & Density, (ton/m ${ }^{3}$ ) & 2.35 & 2.35 & 2.35 & 2.35 \\
3 & VMA, (\%) & 16.7 & 16.90 & 16.4 & 17.5 \\
4 & VIMMarshall, (\%) & 4.8 & 4.59 & 4.47 & 4.6 \\
5 & VIMPRD, (\%) & 2.2 & 2.3 & 2.5 & 2.7 \\
6 & VFB, (\%) & 76.3 & 73.6 & 75.3 & 73.9 \\
7 & Stability, (kg) & 386 & 1049 & 1097 & 1297 \\
8 & Flow, (mm) & 3.8 & 9.8 & 4.1 & 3.8 \\
9 & Marshall Retained Stability, (\%) & 88 & 92.9 & 93.2 & 93 \\
10 & ITSR, (\%) & 79.8 & & 88.8 & - \\
\hline
\end{tabular}

\section{Resilient Modulus}

Most asphalt mixtures for road are not elastic because of the permanent deformation in each loading repetition. However, if the load is relatively small compared to the material strength and the high repeating loading, is so that the deformation occurring at each repetition of loading is nearly completely recoverable and proportional to the loading, therefore the material is considered to be an elastic material [15]. Resilient modulus testing is conducted by direct tensile test. The main factors that need to be considered in the resilient modulus testing for asphalt mixture are temperature and loading frequency [16]. These two factors have great influence on the resilient modulus value. The resilient modulus testing was carried out with a frequency of $0.33 \mathrm{~Hz}$ (pulse repetition period 3000 $\mathrm{ms}$ ), as well as with temperature variations of 25,35 and $45^{\circ} \mathrm{C}$. The peak load used is $1500 \mathrm{~N}$. Testing 
was carried out with two duplo samples, the results shown in Figure 2 are the average of the two duplo samples. As expected, in the same test sample, resilient modulus testing result at temperature of 45 ${ }^{\circ} \mathrm{C}$ has a lower value compared to the testing at temperature of $25^{\circ} \mathrm{C}$ and $35^{\circ} \mathrm{C}$ as seen in Figure 2 .



Figure 2. The Resilient Modulus of ACWC Asphalt Mixture

Figure 2 shows that the testing at temperature of $25^{\circ} \mathrm{C}$ for the ACWC asphalt mixture with the petroleum asphalt pen 60 and the rubberized asphalt have relatively similar resilient modulus value. Differences in the results can be seen from the testing at higher temperatures, at $35^{\circ} \mathrm{C}$ and $45^{\circ} \mathrm{C}$, where the resilient modulus value of rubberized asphalt is higher than that of petroleum asphalt pen 60 . These results prove that rubberized asphalt has higher strength and less sensitive to temperature changes compared to petroleum asphalt pen 60 . Based on resilient modulus value, the performance of ACWC mixture with the addition synthetic polymers modified asphalt (PMB) gives the best results.

\section{Permanent Deformation Resistance}

According to NCHRP [17], permanent deformation or rutting is the surface decline in wheel traces due to the plastic deformation on any or all pavement and subgrade layers. The plastic deformation is generally caused by: (1) densification or compression of one dimension or consolidation, (2) lateral movement or plastic flow of the pavement layer (asphalt mixture, base aggregate/sub base and base). The mixture resistance testing for permanent deformation (rutting) is carried out by using Wheel Tracking Machine (WTM) tool at $45^{\circ} \mathrm{C}$ with load of $6.4 \mathrm{~kg} / \mathrm{cm}^{2}$ (heavy load) for 60 minutes. The deformation test results describe the performance of mixture resistance to the rutting. The wheel tracking tests result for asphalt mixture is presented in Table 4.

According to the data in Table 4, the resistance to permanent deformation (indicated by the dynamic stability values) increased when the rubberized asphalt is used, compared to petroleum asphalt pen 60 . The best performance is shown by the ACWC mixture with the addition synthetic polymers modified asphalt (PMB).

\section{Fatigue Cracks Resistance}

Fatigue is a phenomenon of the emerging of cracks due to repetitive loads caused by repetition of stresses or strains whose limits are still below the material strength limits [18]. Fatigue crack testing is performed to gain the relationship between stress and strain with fatigue life. Fatigue crack testing can be carried out by several methods and using various shapes and sizes of specimens. The mixture resistance testing to fatigue crack conducted at temperature of $20^{\circ} \mathrm{C}$. The specimen is compacted by using Wheel Tracking compactor, its thickness adjusted for fatigue crack testing purposes. A specimen of a $6 \times 5 \times 48 \mathrm{~cm}^{3}$ block is given a repetitive load with a fixed strain, until the block collapsed which is defined when the modulus has reached $50 \%$ of its initial modulus. The test results as seen in Figure 3.

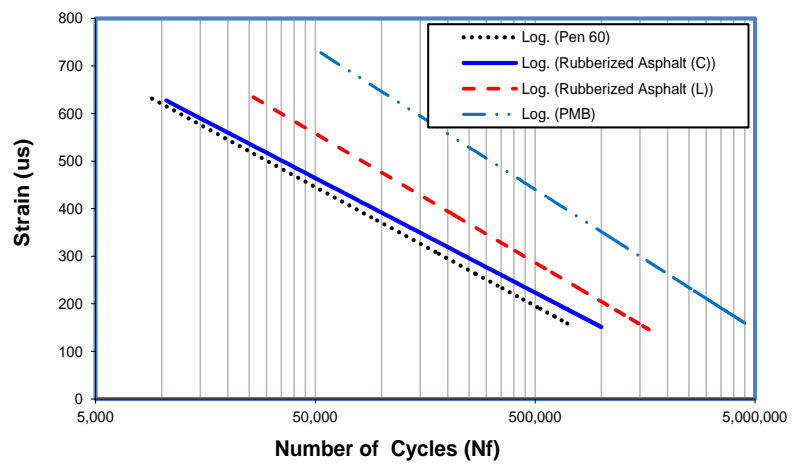

Figure 3. Resistance to Fatigue Cracks Charts

Based on Figure 3 it can be seen that the graph of ACWC with PMB, gives the most number of cycles (repetition) at strain of $200 \mu \mathrm{s}$, that mean PMB has the highest resistance to ACWC mixture fatigue, followed by latex rubberized asphalt, compound rubberized asphalt, and last asphalt pen 60 .

\section{Field Trials}

In order to see the ease of implementation in the project scale, a field trial with 2000 meters length, 7 $\mathrm{m}$ width, and $4 \mathrm{~cm}$ thickness has been conducted for natural rubber pre-vulcanized latex in Bogor West Java, Indonesia. Whilst a field trial for natural rubber compound has been conducted with a length of 500 meters and width of 7 meters and $4 \mathrm{~cm}$ thick in Parung West Java, Indonesia. The field trials showed that the process of mixing pre-vulcanized concentrated latex in asphalt requires about 4 hours to gain a homogeneous mixture. While the mixing of rubber compound has a problem in the process of 
Table 4. Wheel Tracking Test Result

\begin{tabular}{|c|c|c|c|c|c|c|}
\hline \multirow[b]{2}{*}{ Time (minutes) } & \multirow[b]{2}{*}{$\begin{array}{l}\text { Passing } \\
\text { number }\end{array}$} & \multicolumn{4}{|c|}{ Wheel Tracking Test of ACWC Mixture } & \multirow[b]{2}{*}{ Unit } \\
\hline & & Pen 60 & $\begin{array}{l}\text { Rubberized Asphalt } \\
\text { (L) }\end{array}$ & $\begin{array}{l}\text { Rubberized Asphalt } \\
\text { (C) }\end{array}$ & PMB & \\
\hline 0 & 0 & 0 & 0 & 0 & 0 & $\mathrm{Mm}$ \\
\hline 1 & 21 & 1.26 & 1.3 & 0.85 & 0.83 & $\mathrm{Mm}$ \\
\hline 5 & 105 & 2.3 & 2 & 1.41 & 1.39 & $\mathrm{Mm}$ \\
\hline 10 & 210 & 3.04 & 2.77 & 1.8 & 1.76 & $\mathrm{Mm}$ \\
\hline 15 & 315 & 3.62 & 3.11 & 2.06 & 1.95 & $\mathrm{~mm}$ \\
\hline 30 & 630 & 5.12 & 3.78 & 2.67 & 2.3 & $\mathrm{~mm}$ \\
\hline 45 & 945 & 6.52 & 4.21 & 3.15 & 2.58 & $\mathrm{~mm}$ \\
\hline 60 & 1260 & 7.81 & 4.54 & 3.48 & 2.78 & $\mathrm{~mm}$ \\
\hline \multicolumn{2}{|c|}{ Rate of Deformation } & 0.086 & 0.022 & 0.0223 & 0.0136 & $\mathrm{~mm} /$ minutes \\
\hline \multicolumn{2}{|c|}{ Dynamic Stability } & 492 & 1909 & 1884 & 3088 & Passing $/ \mathrm{mm}$ \\
\hline
\end{tabular}

putting it into the asphalt mixer (colloid mill), because the input pipe hole of the colloid mill is relatively small (1 inch), so the rubber compound must be chopped in and put into pipe hole manually. The observation after a 9 month implementation shows that there is no damage on the field trial pavement. The traffic volume on the road segment is approximately 10 - 30 million CESA over the design life (10 years).

\section{Conclusion}

The results show that the rubberized asphalt, both the pre-vulcanized concentrated latex and the rubber compound can improve the physical characteristics of petroleum asphalt pen 60, for instance decreasing penetration value, increasing the softening point value, and increasing the index penetration value. The rubberized asphalt is less sensitive to temperature changes compared to petroleum asphalt pen 60 . The rubberized asphalt is also more elastic which indicated from the greater elastic recovery value. Nevertheless, the improvement of its performance is lower than that of synthetic polymer as bitumen modifier. Meanwhile based on the performance of ACWC mix, ACWC with rubberized asphalt can improve the resilient modulus, resistance of permanent deformation and fatigue cracks compare with the ACWC without modifier, but the improvement is still below the performance of ACWC with PMB.

\section{Acknowledgement}

The authors would like to give the highest appreciation to the Institute of Road Engineering, Bandung, Indonesia for the support and funding the research, both in laboratory testing and during the field application.

\section{References}

1. Indonesia Investments, Karet (alam). Available at https://www.indonesia-investments.com/id/ bisnis/komoditas/karet/item185?. Accessed January 18, 2018
2. Ruggles, C. S., The Efficient Use of Environmentally-Friendly Natural Rubber Latex in Road Construction-Past, Present and the Future, Seminar "Rubber in Transport", 2004. Available at https://www.revertex.com. Accessed July 10, 2018.

3. Tuntiworawit, N., Lavavsiri, D., and Phromsorn, C., The Modification of Asphalt with Natural Rubber Latex, Proceedings of the Eastern Asia Society for Transportation Studies, 5, 2005, pp. 679-694.

4. Wen, Y., Wang, Y., Zhao, K., and Sumalee, A, The Use of Natural Rubber Latex as a Renewable and Sustainable Modifier of Asphalt Binder, International Journal of Pavement Engineering, 18(6), 2017, pp. 547-559.

5. Vichitcholchai, N., Panmai, J., Na-Ranong, N., Modification of Asphalt Cement by Natural Rubber for Pavement Construction, Rubber Thai Journal, 1, 2012, pp. 32-39. Available at https://www.rubberthai.com. Accessed July 9, 2018.

6. Okieimen, F. E. and Akinlabi, A. K., Processing Characteristics and Physicomechanical Properties of Natural Rubber and Liquid Natural Rubber Blends, Journal of Applied Polymer Science. 85(5), 2002, pp. 1070-1076.

7. Zborowski, A. and Kaloush, K. E., Predictive Equation to Evaluate Thermal Fracture of Asphalt Rubber Mixtures, Road Materials and Pavement Design, 8(4), 2007, pp. 819-833.

8. AASHTO T 245: 2014, Standard Method of Test for Resistance to Plastic Flow of Asphalt Mixture using Marshall Apparatus, American Association of State Highway and Transportation Officials, Washington, D.C., 2014.

9. AASHTO T 283: 2014, Resistance of Compacted Bituminous Mixture to Moisture Induced Damage for Super-pave, American Association of State Highway and Transportation Officials, Washington, D.C., 2014.

10. ASTM D 7369: 2011, Standard Test Method for Determining the Resilient Modulus of Bituminous Mixture, American Standard Testing and Material, Washington, D.C., 2011. 
11. JRA, Manual for Design and Construction of Asphalt Pavement, Japan Road Association, Japan, 1980.

12. ASTM D 7369, Determining the Fatigue Life of Compacted Hot Mix Asphalt (HMA) Subjected to Repeated Flexural Bending, American Standard Testing and Material, Washington, D.C., 2011.

13. SNI 8198, Spesifikasi Campuran Beraspal Panas Bergradasi Menerus (Laston), Badan Standarisasi Nasional, Jakarta, 2015.

14. Shell, The Shell Bitumen Handbook. Sixth edition, Shell, UK National, 2015.

15. Huang Y.H., Pavement Analysis and Design second edition, Prentice Hall, New Jersey, 2004.
16. Suaryana, N., Perfomance Evaluation of Stone Matrix Asphalt using Indonesian Natural Rock Asphalt as Stabilizer, International Journal of Pavement Research and Technology, Jhongli: Chinese Society of Pavement Engineering, 9(5), 2016, pp. 387-392.

17. National Cooperative Highway Research Program (NCHRP): 2004, Guide for MechanisticEmpirical Design, Part 3 Chapter 3 Flexible Design, Transportation Research Board, Washington DC.

18. Yoder, E. J. and Witczak, M. W., Principles of Pavement Design, John Wiley \& Sons. Inc, New York, 1975. 